\title{
THE GIANT HOUSE SPIDER IN SASKATCHEWAN
}

D.J. BUCKLE, 620 Albert Avenue, Saskatoon, SK. S7N 1 G7 and R.L.

RANDELL, Department of Biology, University of Saskatchewan, Saskatoon, SK. S7N OWO

In May of 1994 Moe Koetting brought a large Agelenid spider to the University of Saskatchewan Department of Biology for identification. She had found it walking across the ceiling of her house on an acreage near Bradwell, about $30 \mathrm{~km}$ southeast of Saskatoon. It proved to be a mature female of the Giant House Spider (Tegenaria gigantea Chamberlin \& Ivie). This is the first time this species has been found in Saskatchewan.

The Giant House Spider is the large hairy spider which has horrified generations of Englishmen by dashing wildly across the carpet, lurking in a tangle of cobwebs behind the water closet, or scrambling desperately to escape from the bathtub into which it has fallen. Flanders and Swan immortalized the beast in their song 'The Spider'. It was thus with considerable enthusiasm that we hurried off to investigate Ms. Koetting's house and determine if this arachnological classic had become established here in Saskatchewan.

Ms. Koetting mentioned having seen several spiders, similar to the one she caught, moving across the walls of her house during the year she had occupied it but she had found no webs. Armed with flashlights we ventured into the two-foothigh crawl space beneath the house. Water pipes in the crawl space were not insulated so, presumably, winter temperatures remain above freezing there. Giant House Spider webs were common between stringers. They were most abundant near plumbing pipes where a small leak kept the humidity high and near a vent where small insects could enter. Many of the webs appeared to be unoccupied. We saw three halfgrown juveniles and captured one of these. Egg sacs were present in four webs in loose clusters of up to ten. The new appearance of most of the webbing and the limited number of webs with egg sacs suggest that the colony is probably not more than one or two years old.

The Giant House Spider is native to Europe. It first became established in North America in the Victoria/Vancouver area of coastal British Columbia where it has been known since the 1920s. ${ }^{2}$ It appeared in the Seattle area of Washington state in the $1960 \mathrm{~s}^{3}$ and has gradually spread across British Columbia. Specimens from British Columbia were collected from Lillooet in 1950, Campbell River in 1969, Kelowna and Williams Lake in 1988, and Summerland in 1993. In recent years it has begun to appear in Alberta. Leech and Steiner ${ }^{7}$ reported Giant House Spiders from houses in Edmonton, Saint Albert and Spruce Grove between 1987 and 1992. It has also been taken from houses in Calgary in 1987 and 1989 and Cardston in 1994.

The Giant House Spider is an 
impressive spider. Females are 12 $18 \mathrm{~mm}$ in length with a leg span of up to $60 \mathrm{~mm}$. Males are smaller (10$14 \mathrm{~mm}$ long) and more slender than females, but have longer legs. Spiders likely to be confused with $T$. gigantea are our native funnel-web spiders of the genus Agelenopsis which are rarely found indoors and gigantea's small relative, the Common House Spider (Tegeneria domestica Clerck). T. domestica is also a European introduction. It is found in buildings throughout the province. Adults are 6-11 $\mathrm{mm}$ in length. The Hobo Spider (Tegenaria agrestis Walckenaer) is another introduction from Europe. It has become established in British Columbia, Washington, Oregon and Idaho $^{4,13}$ and should be looked for in Alberta and Saskatchewan. The Hobo Spider is about the same size as the Common House Spider and very similar in appearance. It can only be distinguished by small details of its anatomy. It is a medically significant species whose bite can produce local necrosis which is very slow to heal. ${ }^{4,12}$

A number of useful references are available to anyone interested in the identification of the house-dwelling Tegenerias. $4,9,10,11$ While the Giant House Spider is one of the best known if least loved spiders of Britain and northern Europe, its nomenclatural history has been fraught with confusion and some background information is necessary for anyone dealing with the literature. During the first half of this century the Giant House Spider was considered to be a single species and went variously under the names atrica (C.L. Koch 1843), saeva (Blackwall 1844), or larva (Simon 1875). Workers ${ }^{5,6}$ in the 1950s demonstrated that the Giant House Spider was really two very similar species, atrica and saeva, and that larva was a junior synonym of atrica. In 1975 Locket $^{8}$ showed that this group included a third species which he named propinqua. Crawford and Locket $^{3}$ found that this species had previously been named gigantea by Chamberlin and Ivie in 1935. ${ }^{2}$ Chamberlin and Ivie had based their name on specimens from the introduced population on Vancouver Island, British Columbia. So far, gigantea is the only one of the three species to have been found in North America. Brignoli ${ }^{1}$ argued that gigantea is a synonym of duellica (Simon 1875) and he has been followed by a number of recent authors. However, as the type specimens of duellica cannot be located, and Simon's description and illustrations are insufficient to conclusively place the species, it seems best to treat duellica as a nomin dubium and continue to use gigantea.

Acknowledgements We would like to thank Charles Dondale (Biosystematics Research Institute, Ottawa), Burton Schaber (Agriculture Canada Research Station, Lethbridge), and Walter Charles (Summerland) who provided locality records for British Columbia and Alberta.

1. BRIGNOLI, P.M. 1978. Quelques notes sur les Agelenidae, Hahniidae, Oxyopidae et Pisauridae de France et d'Espagne (Araneae). Rev. suisse Zool. 85: 265-94.

2. CHAMBERLIN, R.V. and W. IVIE. 1935. Miscellaneous new American spiders. Bull. Univ. Utah 26: 1-79.

3. CRAWFORD, R. and G.H. LOCKET. 1976. The occurrence of Tegenaria gigantea Chamberlin \& Ivie (1935) in North America and Western Europe. Bull. Br. arachnol. Soc. 3: 199.

4. CRAWFORD, R. and D.K. VEST. 1988. The Hobo Spider and other European house spiders. Burke Mus. Ed. Bull. 1: 1-4.

5. DENIS, J. 1959. Sur la synonymie des Tegenaria du groupe atrica C.L. Koch. Bull. Soc. Hist. Nat. Toulouse 94: 172-76.

6. DRESCO, E. 1957. Description d'une 
espèce nouvelle de Tegenaria et remarques sur $T$. saeva Black. et atrica C.L. Koch. Vie et Milieu 8: 211-20.

7. L.EECH, R. \& M. STEINER. 1992. Metaltela simoni (Keyserling, 1878) (Amaurobiidae) new to Canada, and records for Tegenaria gigantea Chamberlin and Ivie, 1935, (Agelenidae) in Alberta and British Columbia. Can. Entomol. 124: 419-20.

8. LOCKET, G.H. 1975. The identity of Blackwall's Tegenaria saeva (Araneae, Agelenidae). Bull Br. arachol. Soc. 3: 85-90.

9. MERRETT, P. 1980. Notes on the variation, identification and distribution of British species of the Tegeneria atrica group (Araneae, Agelenidae). Bull. Br. arachnol. Soc. 5: 1-8.
10. ROBERTS, M.J. 1985. The Spiders of Great Britain and Ireland, Vol. 1. Harley Books, Colchester.

11. ROTH, V.D. 1968. The spider genus Tegenaria in the Western Hemisphere (Agelenidae). Amer. Mus. Novitates 2323: 1-33.

12. VEST, D.K. 1987. Necrotic arachnidism in the northwest United States and its probable relationship to Tegenaria agrestis (Walckenaer) spiders. Toxicon 25: 175-84.

13. WEST, R., C.D. DONDALE and R.A. RING. 1984. A revised checklist of the spiders of British Columbia. J. Entomol. Soc. Brit. Columbia 81: 80-98.

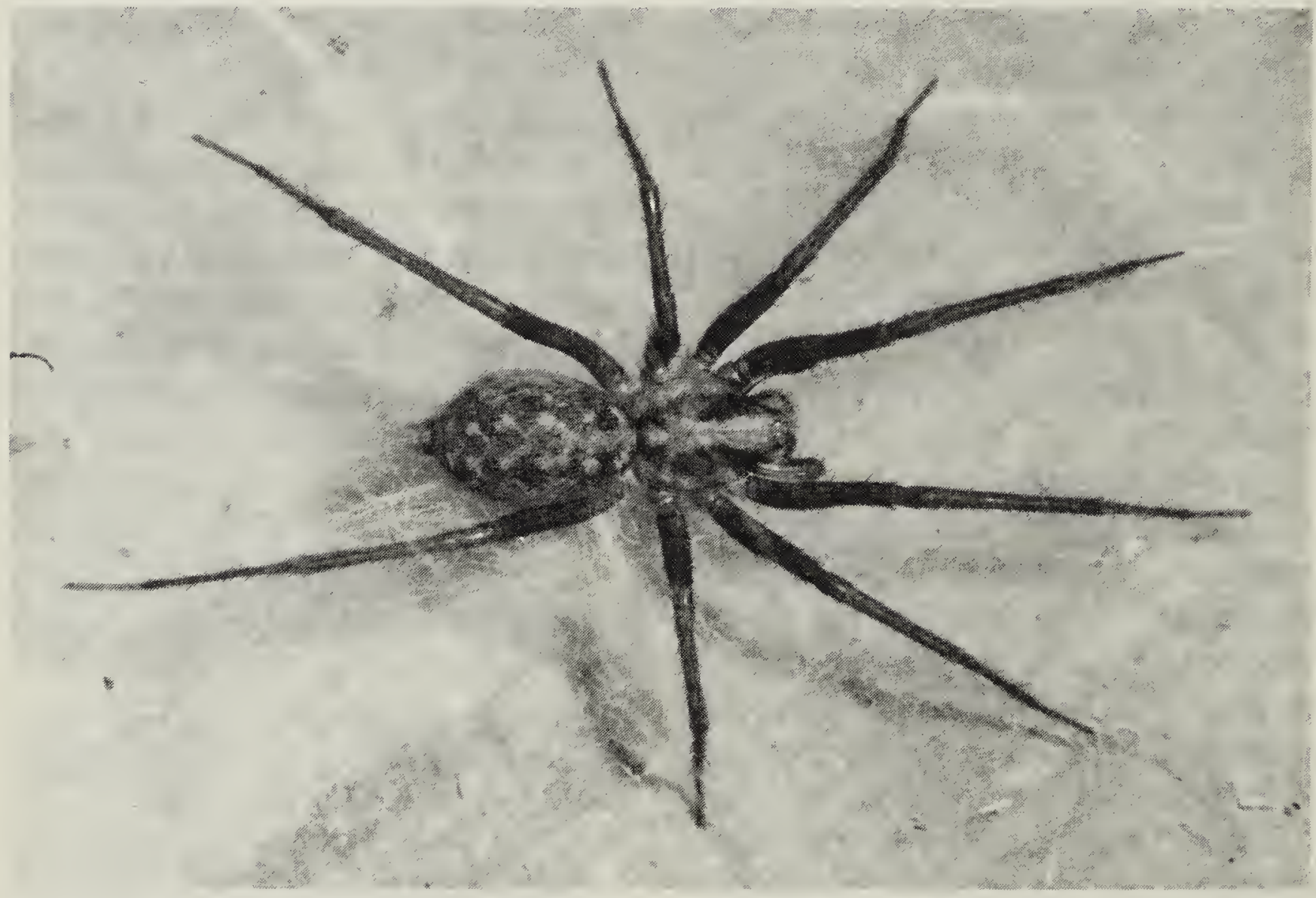

Giant House Spider (Tegeneria gigantea)

Don Buckle

"Many years ago, the Greeks equated butterflies with the souls of people, using the Greek word for 'psyche' for bcth. One does not have to believe in Greek mythology to know that in a world without butterflies, the souls of all people would be greatly diminished." Jeffrey Glassberg, Butterflying through binoculars. 